\title{
Василина Ковальова
}

\section{РОЗРОБКА КОМПЛЕКСНОГО КОРЕКТОРА ДЛЯ СТАБІЛІЗАЦЇ̈ ЯКОСТІ БОРОШНА НА БОРОШНОМЕЛЬНИХ ЗАВОДАХ}

\footnotetext{
Актуальність теми дослідження. Розробка борошняної суміші для поліпшення хлібопекарських властивостей борошна з використанням ферментних препаратів - перспективний інноваційний напрям розвитку борошномельної промисловості.

Постановка проблеми. Використання ферментних препаратів на борочномельних заводах України дасть можливість максимально використати потенціал сировини, стабілізувати якість борошна й задовольнити потреби хлібопекарської та кондитерської промисловості.

Аналіз останніх джсерел і публікацій. 3 метою покращення якості хліба у хлібопекарській промисловості використовують харчові добавки та поліпшувачі різного принципу дії. Розроблені рецептури їх внесення в технологічну лінію виробництва борошняних виробів.
}

Виділення недосліджених частин загальної проблеми. У літературі відсутня інформація щзодо використання як поліпшувачів ферментних препаратів направленої дї безпосередньо на борошномельних заводах України для стабілізачії якості готової продукиії.

Постановка завдання. Метою роботи є поліпшення хлібопекарської якості пшеничного борошна шляхом внесення ферментних препаратів.

Виклад основного матеріалу. У статі наведено дослідження з коригування якості украӥнського борошна вищого сорту з низькими хлібопекарськими властивостями, а саме: низькою амілолітичною активністю (ЧП - 460 с) $i$ пружними властивостями клейковини, показник ІДК - 51 ум. од. У ролі коректорів були використані ферментні препарати німецького виробника Мюленхімі з амілазною й геміцелюлазною активністю (Alphaтаlt A 6003) $i$ сірковмісна амінокислота циистеїн (Porit-L). За результатами пробного лабораторного випікання встановлено вплив кожного коректора як окремо, так $і$ в комплексі.

Висновки відповідно до статmі. Встановлено, щуо використання комплексу ферменту Alphaтаlt A 6003 i амінокислоти Porit-L сприяє покрашенню органолептичних і фізичних показників хліба: збільшення питомого об'єму в 2,1 раза, пористості з 71 до $84 \%$ У статті вперше наведено рецептуру комплексу ферментів для коригування якості украӥнського борошна з низькою ферментативною активністю. Результати досліджень можуть бути використані борошномельними виробництвами для стабілізації якості кінцевої продукиії.

Ключові слова: пиеничне борошно; ферментні препарати; клейковина; Alphamalt A6003; Porit-L; $\alpha$-aмiлаза; геміцелюлаза.

Рис.: 4. Бібл.: 12

Актуальність теми дослідження. Підвищення якості продуктів харчування в наш час $є$ однією з основних задач. Шляхи ії вирішення різноманітні й пов'язані насамперед із ресурсозбереженням, удосконаленням асортименту продукції, поліпшенням рецептур і технологій, використанням нетрадиційної сировини, наданням їжі профілактичної спрямованості й багатьох захисних властивостей [1]. Особливо важливим це $є$ у процесі виробництва товарів масового споживання, до яких відноситься передусім хліб [2].

Постановка проблеми. Одним з основних завдань борошномельної промисловості $\epsilon$ випуск продукції з хорошими споживчими властивостями. Однак відмінності в типах i сортах пшениці, погодно-кліматичних і агротехнічних умовах вирощування та збору врожаю, режимах зберігання й технологічних схемах переробки зерна зумовлюють різну його якість [3]. Поліпшення, коригування властивостей борошна необхідні для забезпечення його стандартної якості і для виробництва широкого асортименту хлібобулочних та кондитерських виробів [4].

Разом 3 цим пріоритетними завданнями хлібопечення є також стабілізація властивостей основної сировини, вдосконалення асортименту виробів покращеної якості, поліпшення смаку й аромату хліба при використанні прискорених технологій, а також розробка способів продовження терміну зберігання свіжості готової продукції. Реалізація зазначених завдань грунтується на цілеспрямованому застосуванні харчових добавок і поліпшувачів [5].

Аналіз останніх досліджень і публікацій. У сучасному хлібопеченні застосовуються харчові добавки, використання яких $є$ необхідним через багато причин, а саме:

- вдосконалення технології виробництва;

- розширення асортименту хлібобулочних виробів з більш тривалим терміном збереження свіжості та ін.;

(C) Ковальова В. П., 2018 
- нестабільності якості борошна;

- різноманітності видів і властивостей сировини [6].

Переважно більшість добавок і поліпшувачів не мають харчового значення, але одні 3 них зовсім нешкідливі, а інші навпаки - навіть можуть загрожувати здоров'ю людини. Всі добавки регламентуються медико-біологічними вимогами й санітарними нормами якості продовольчої сировини і харчових продуктів [3; 7].

У хлібопеченні застосовуються: поліпшувачі окисної дії, поліпшувачі відновної дії, поверхнево-активні речовини, ферментні препарати, модифіковані крохмалі; мінеральні солі, консерванти, суха пшенична клейковина, сухі закваски (підкислювачі), ароматичні та смакові добавки [8].

Отримати хліб необхідної якості можна лише тоді, коли в процесі тістоведення оптимально поєднуються швидкості мікробіологічних процесів і біохімічних перетворень. Під дією ферментів протікає гідроліз білків і вуглеводів, що деякою мірою сприяє інтенсифікації цих перетворень і позитивно позначається на якості хліба [6; 9]. У хлібопеченні застосування таких ферментів, як $\alpha$-амілаза і гемицеллюлаза сприяє зниженню витрат борошна, поліпшенню якості тіста, уповільненню черствіння, а також розширенню виробництва охолодженого й замороженого тіста [10]. Ці ферменти беруть участь у розщепленні крохмалю до простих цукрів, що необхідно для кращого харчування дріжджів, підвищення водопоглинальної і газоутворюючої здатності тіста, забезпечення стабільності тістових заготовок, запобігання затягуванню тіста. Ферменти також сприяють утворенню більшого питомого об'єму хліба, отримання тонкої скоринки, підвищенню еластичності м'якушки й поліпшенню його структури [11].

Виділення недосліджених частин загальної проблеми. Аналіз публікацій показав, що активно досліджується питання використання ферментних препаратів для покращення якості борошняних виробів. У результаті проведеного аналізу також виявлено, що відсутня інформація відносно використання ферментів безпосередньо на борошномельних заводах України. В європейських країнах давно існує досвід внесення таких коректорів у борошно, однак для українських виробників таке рішення не є достатньо поширеними у зв'язку з відсутністю науково обгрунтованої бази.

Мета статті. Метою дослідження є розробка комплексного поліпшувача хлібопекарської якості пшеничного борошна українських виробників з низькою амілолітичною активністю і пружними властивостями клейковинного каркаса.

Як об’єкт досліджували:

- пшеничне борошно вищого сорту українського виробництва (ГСТУ 46.004-99);

- ферментний препарат фірми Мюленхімі $\alpha$-амілаза 3 геміцелюлазною активністю Alphamalt A 6003;

- сірковмісна амінокислота цистеїн фірми Мюленхімі Porit-L.

Виклад основного матеріалу. Згідно з вимогами ГСТУ 46.004-99 «Борошно пшеничне. Технічні умови» борошно вищого сорту повинне відповідати таким показникам: вологість - не більше $15 \%$, кількість клейковини - не менше $24 \%$, якість клейковини не нижче II групи, зольність - не більше 0,55 \%, білість - не менше 54 ум. од., число падіння - не менше 160 с.

Всі показники якості визначалися згідно з методиками діючих в Україні стандартів: ГОСТ 9404-88 «Борошно і висівки. Метод визначення вологості»; ГОСТ 27839-88 «Борошно пшеничне. Метод визначення кількості і якості клейковини»; ГОСТ 27494-87 «Борошно і висівки. Метод визначення зольності»; ГОСТ 26361-84 «Борошно. Метод визначення білості»; ГОСТ 27676-88 «Зерно і продукти його переробки. Метод визначення числа падіння».

Для комплексної оцінки хлібопекарських властивостей борошна проводили пробну лабораторну випічку формового хліба згідно з методикою ГОСТ 27669-88 у перерахунку на 100 г борошна. 3 огляду на вологість борошна визначалась кількість необхідної 
TECHNICAL SCIENCES AND TECHNOLOGIES

води для замісу тіста. У рецептурі також вказано кількість дріжджів (3 г), цукру (4 г) та солі (1,3 г). Замішування і формування тіста проводилось вручну. У процесі бродіння в термостаті при температурі $(31 \pm 1){ }^{\circ} \mathrm{C}$ тісту дають три обминання через 90, 150 і 180 хв від початку бродіння. Після закінчення бродіння тістові заготовки кладуть у форми, попередньо змащені олією. Остаточне вистоювання сформованих заготовок проводиться при температурі $32 \ldots 35{ }^{\circ} \mathrm{C}$ та відносній вологості повітря $70 \ldots 85 \%$. Кінець вистоювання визначають за станом та видом тістових заготовок, не допускаючи їх опадання. Хліб випікають у лабораторних печах при температурі $220 \ldots 230{ }^{\circ} \mathrm{C}$ з обов язковим зволоженням пекарної камери. Тривалість випікання хліба складає $20 \ldots 25^{\circ} \mathrm{C}$.

Основними показниками якості хліба є: органолептична оцінка (зовнішній вигляд хліба, поверхня кірки і їі колір, стан м’якушки, характер пір), обсяг, пористість, питомий об’єм.

Оцінка якості борошна показала такі результати: вологість - 14,9 \%; кількість клейковини - 25,4 \%; якість клейковини - 51 ум. од.; білість - 56 ум. од.; зольність - 0,54 \%; ЧП - 460 с. Таке борошно характеризується низькими хлібопекарськими властивостями через міцну клейковину (ІДК 51 ум. од.) і низьку амілолітичну активність (ЧП 460 с). Пробна випічка показала, що контрольний зразок має рівномірну золотисту скоринку, але невисокий об'єм $\left(300 \mathrm{~cm}^{3}\right)$, невелику пористість $(71 \%)$ і середню еластичність м'якушки, що пояснюється низькою ферментативною активністю вихідного зразка борошна. Для поліпшення якості такого борошна було прийнято рішення використовувати ферментний препарат Alphamalt A 6003 і амінокислоту Porit-L.

Згідно 3 рекомендаціями виробника дозування ферментного препарату Alphamalt A 6003 становить 0,08-0,15 г/кг. Такий широкий діапазон вказує на те, що використання різної кількості ферменту залежить від якості борошна і бажаних змін у ньому. У роботі були досліджені контрольний зразок - борошно без ферментних препаратів (проба 1) і 3 варіанти дозування: проба 2 - 0,08 г/кг (мінімальне дозування); проба 3 - 0,12 г/кг (середнє дозування); проба 4 - 0,15 г/кг (максимальне дозування).

При внесенні в борошно мінімального дозування Alphamalt A 6003 покращився зовнішній вигляд і збільшився питомий об'єм хліба з 1,9 до 3,2 cм³/Г (рис. 1). Це свідчить про те, що навіть у такій невеликій кількості ферментний препарат збільшив амілолітичну активність борошна і покращив якість хліба. Найкращий результат мав хліб з внесенням середнього дозування: так, питомий об'єм збільшився в 1,7 раза, покращилась пористість 371 до 80 \% при цьому вона стала рівномірною з тонкими стінками пор. Максимальне дозування не привело до подальшого зростання якості хліба, а навпаки, результати схожі з мінімальними, тому раціональним для цього зразка борошна є середнє дозування - 0,12 г/кг.

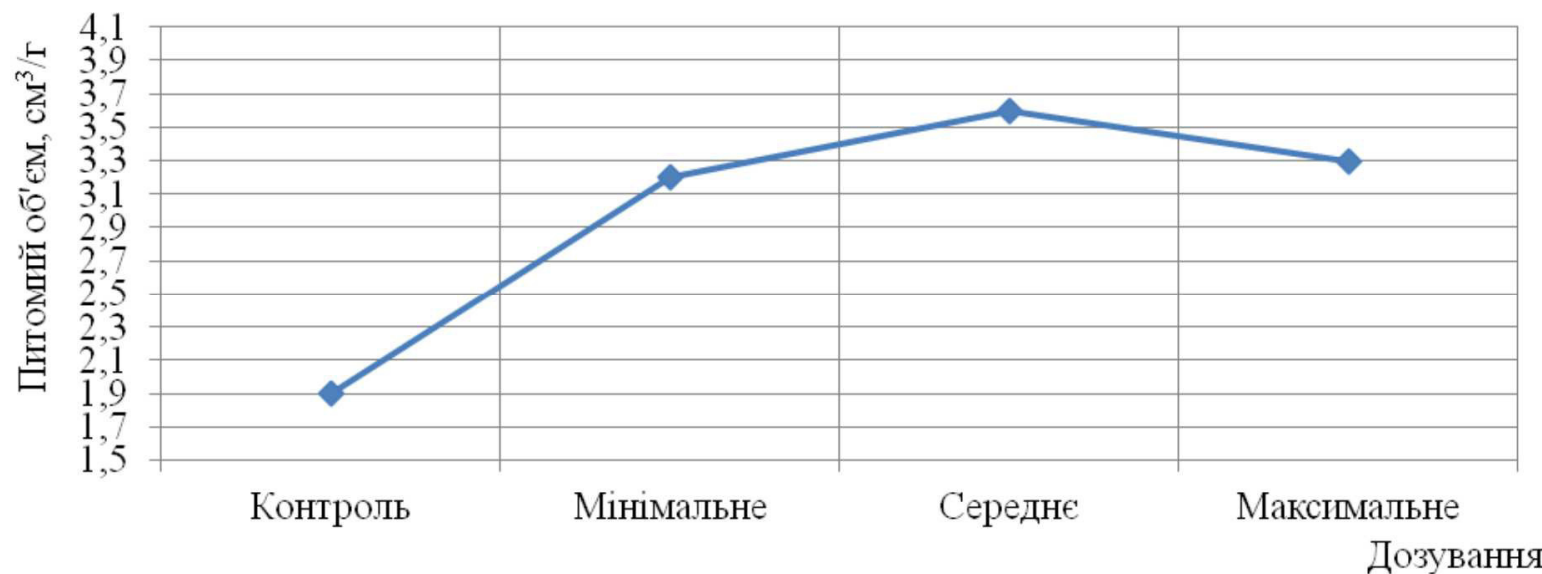

Рис. 1. Питомий об'єм хліба при різних дозуваннях ферментного npenapamy Alphamalt A 6003 
TECHNICAL SCIENCES AND TECHNOLOGIES

Porit-L вводився в борошно в таких дозуваннях: мінімальне - 0,05 г/кг; середнє 0,1 г/кг; максимальне - 0,2 г/кг. Амінокислота цистеїн не чинила суттєвого впливу на якість хліба, при максимальному дозуванні питомий об'єм хліба показав найкращий результат і збільшився з 1,9 до 2,2 cм³/г (рис. 2), але такі зміни не набагато кращі за мінімальне і середнє дозування, що мають однакові результати: так, при мінімальному і середньому дозуваннях питомий об'єм збільшився в 1,1 раза, а при максимальному в 1,2. Такі зміни якості пов'язані з невисоким вмістом клейковини (білка) і низькою газоутримуючою здатністю досліджуваного зразка борошна, яка при розслабленні клейковини зменшується.

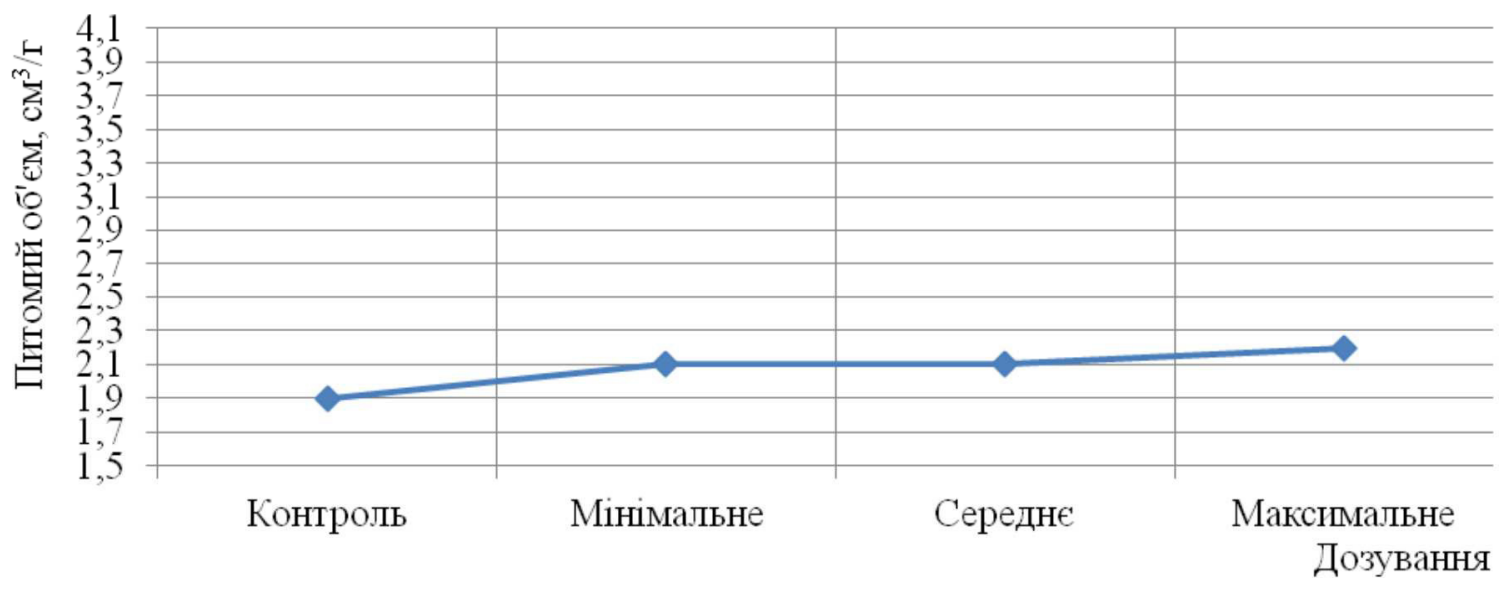

Рис. 2. Питомий об'єм хліба при різних дозуваннях ферментного препарату Porit-L

На підставі отриманих даних було прийнято рішення про застосування комплексу $\alpha$ амілази з геміцелюлазною активністю і цистеїну для визначення комплексного впливу на якість хліба.

Для поліпшення якості хліба були складені комплекси з Alphamalt A 6003 i Porit-L в мінімальних, середніх і максимальних дозуваннях. При проведенні пробної лабораторної випічки хліба зовнішній вигляд з додаванням коректорів покращився, поверхня хліба стала більш рівномірною з золотавою скоринкою, покращився також характер пор, смак і аромат виробів (рис. 3).

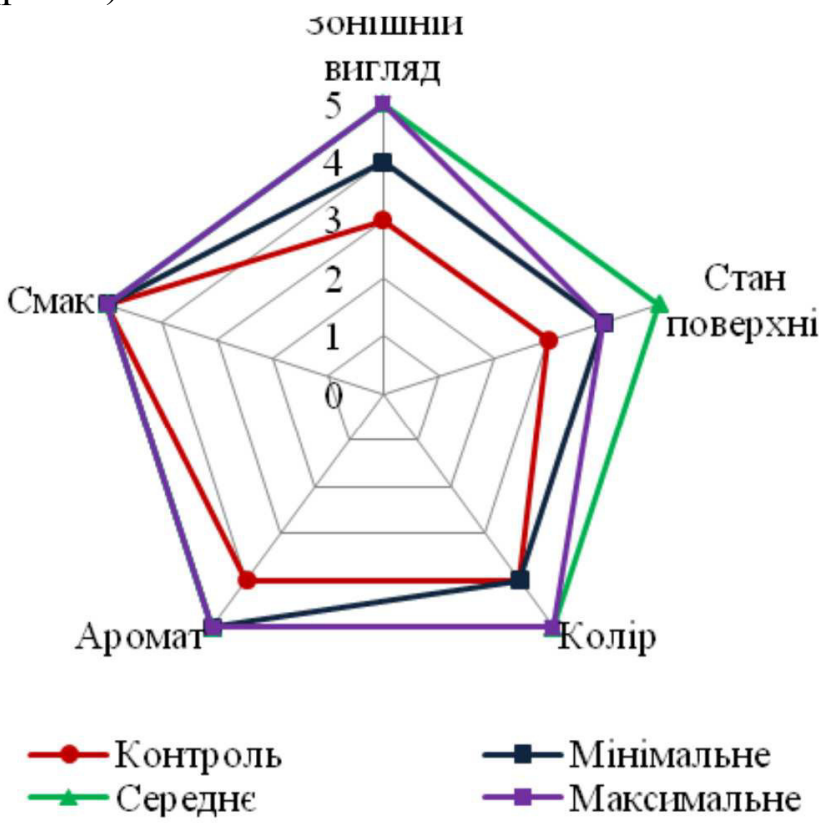

Рис. 3. Бальна оцінка якості хліба з додаванням комплексу ферментів 
Аналіз якості хліба показав, що вже при мінімальному дозуванні спостерігаються значне збільшення питомого об'єму хліба з 1,9 до 3,6 cм³/г. При середньому дозуванні питомий об'єм збільшився до 3,9 см³/г, максимальне дозування призводить до зменшення питомого об’єму і збільшення пористості з нерівномірно розподіленими порами. Найкращі результати якості хліба показав комплекс покращувачів у середніх дозуваннях (рис. 4).

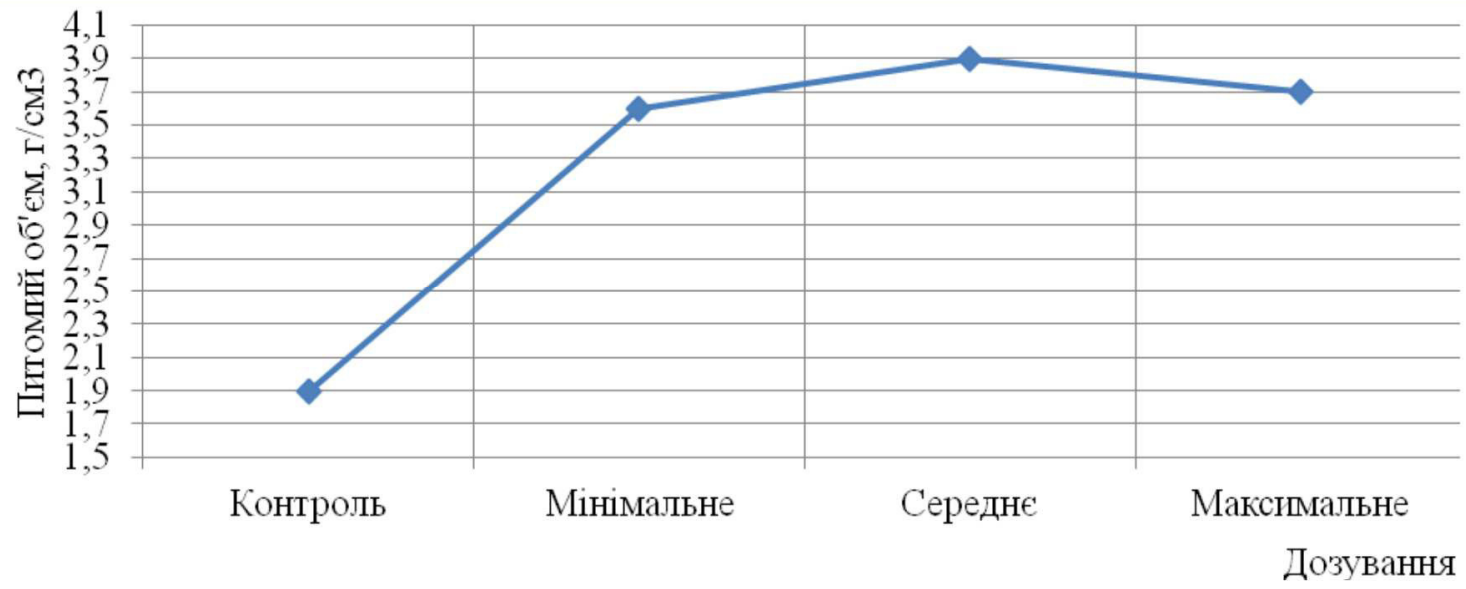

Рис. 4. Питомий об'єм хліба при різних дозуваннях комплексу з Alphamalt A 6003 i Porit-L

Ферментні препарати різного принципу дії дозволяють регулювати спиртове бродіння в тісті, покращувати газоутворюючу й газоутримуючу здатність, інтенсифікувати технологічний процес виробництва хліба.

Alphamalt A 6003 компенсує недолік $\alpha$-амілази в борошні, збільшує накопичення декстринів, збільшує газоутворюючу і цукроутворюючу здатність борошна, інтенсифікує технологічний процес. Завдяки геміцелюлазної активності він діє на нерозчинні високомолекулярні пентозани, збільшує частку низькомолекулярних пентозанов, що сприяє утворенню більш міцного каркаса клейковини, сприяє збільшенню частки зв'язаної вологи в тісті, що викликає покращення структурно-механічних властивостей тіста. Саме для досліджуваного зразка борошна, отриманого за скороченою схемою технологічного процесу, характерна наявність високої кількості пентозанів, які погіршують якість хліба, тому використання Alphamalt A 6003 є доцільним рішенням.

Porit-L, тобто цистеїн, позитивно впливає на міцну клейковину, розслаблює iii, прискорюючи дозрівання тіста. Ослаблення клейковини, збільшення ії розтяжності при внесенні цистеїну пояснюється зміною співвідношення сульфгідрильних груп і -SS-зв'язків в білках клейковини.

\section{Висновки відповідно до статті.}

1. Норми введення ферментного препарату Alphamalt A 6003 для українського борошна зі зниженою ферментативною активністю становлять: мінімальне - 0,08 г/кг, середнє - 0,12 г/кг, що покращує якість і об'єм хліба.

2. Обгрунтована рецептура комплексу поліпшувачів для стабілізації якості українського борошна: мінімальнє дозування - Alphamalt A 6003 - 0,08 г/кг, Porit-L 0,05 г/кг; середнє дозування - Alphamalt A 6003 - 0,12 г/кг; Porit-L - 0,05 г/кг - 0,1 г/кг.

3. Ці комплекси рекомендовані для використання на борошномельних заводах, особливо зі скороченою схемою технологічного процесу, що призводить до покращення якості готової продукції та підвищення іiї конкурентоспроможності. 


\section{Список використаних джерел}

TECHNICAL SCIENCES AND TECHNOLOGIES

1. Ауэрман Л. Я. Технология хлебопекарного производства : учебник / Л. Я. Ауэрман ; под общ. ред. Л. И. Пучковой. - 9-е изд., перераб. и доп. - СПб. : Профессия, 2005. - 416 с.

2. Матвеева И. В. Пищевые добавки и хлебопекарные улучшители в качестве мучных изделий / И. В. Матвеева, И. Г. Белявская. - М. : МГУПП, 2001. - 115 с.

3. Дробот B. I. Харчові добавки та їх функціональна роль у технологічному процесі / В. І. Дробот // Хранение и переработка зерна. - 2003. - № 9. - С. 25-27.

4. Косован А. П. Применение хлебопекарных улучшителей для регулирования качества муки / А. П. Косован. Г. Ф. Дремучева // Пищевая промышленность. - 2003. - № 12. - С. 44-45.

5. Матвеева И. В. Концепция и технологические решения применения хлебопекарных улучшителей / И. В. Матвеева // Пищевая промышленность. - 2005. - № 5. - С. 20-23.

6. Чижикова О. Г. Эффективное средство повышения качества хлеба - хлебопекарные улучшители / О. Г. Чижикова, Л. О. Коршенко // Вестник Дальневосточной государственной академии экономики и управления. - 1998. - № 1/5. - С. 91-97.

7. Полякова A. В. Вплив рослинних добавок на якість клейковинного комплексу пшеничного борошна / А. В. Полякова, О. О. Шубін // Вісник ХНТУСГ ім. П. Василенка. - 2007. Вип. 58. - С. 250-254.

8. Матвеева И. В. Корректировка качества муки на основе ферментных препаратов / И. В. Матвеева // Хлебопродукты. - 2007. - № 3. - С. 55-57.

9. Дробот В. Поговоримо ще раз про харчові добавки та їх функціональну роль в технологічному процесі / В. Дробот // Хлібопекарська і кондитерська промисловість України. - 2011. № 5. - C. $8-10$.

10. Мелешкина E. А. Применение пищевых добавок на мельницах / Е. А. Мелешкина // Хлебопродукты. - 2005. - № 11. - С. 40-42.

11. Кондратьев И. А. Применение ферментных препаратов на мукомольных заводах / И. А. Кондратьев, А. И. Кондратьев // Зерновое хозяйство. - 2002. - № 5. - С. 25-26.

12. Hamer R. J. Enzymes in the baking industry // Enzymes in Food Processing / G. A. Tucker, L. F. J. Woods (Eds.). - Glasgow: Blackie, 1991. - Pp. 168-193.

\section{References}

1. Auerman, L. (2005). Tekhnologiia khlebopekarnogo proizvodstva: uchebnik [Technology of bakery production]. Petersburg: Professiia [in Russian].

2. Matveeva, I. V. \& Beliavskaia, I. G. (2001). Pishchevye dobavki i khlebopekarnye uluchshiteli v kachestve muchnykh izdelii [Food additives and bakery improvers as flour products]. Moscow: MGUPP [in Russian].

3. Drobot, V. I. (2003). Kharchovi dobavky ta ikh funktsionalna rol u tekhnolohichnomu protsesi [Nutritional supplements and their functional role in the technological process]. Khranenie $i$ pererabotka zerna - Storage and processing of grain, 9, 25-27 [in Ukrainian].

4. Kosovan, A. P. \& Dremucheva, G. F. (2003). Primenenie khlebopekarnykh uluchshitelei dlia regulirovaniia kachestva muki [Application of bakery improvers for flour quality control]. Pishchevaia promyshlennost - Food industry, 12, 44-45 [in Russian].

5. Matveeva, I. V. (2005). Kontceptsiia i tekhnologicheskie resheniia primeneniia khlebopekarnykh uluchshitelei [The concept and technological solutions for the use of bakery improvers]. Pishchevaia promyshlennost - Food industry, 5, 20-23 [in Russian].

6. Chizhikova, O. G., Korshenko, L. O. (1998). Effektivnoe sredstvo povysheniia kachestva khle$\mathrm{ba}$ - khlebopekarnye uluchshiteli [An effective means of improving the quality of bread - bakery improvers]. Vestnik Dalnevostochnoi gosudarstvennoi akademii ekonomiki i upravleniia - Bulletin of the Far Eastern State Academy of Economics and Management, 1 (5), 91-97 [in Russian].

7. Poliakova, A. V. \& Shubin, O. O. (2007). Vplyv roslynykh dobavok na yakist kleikovynnoho kompleksu pshenychnoho boroshna [Influence of plant additives on the quality of gluten-free complex of wheat flour]. Visnyk KhNTUSH im. P. Vasylenka - Herald of KhNTUSG them. P. Vasilenko, 58, 250-254 [in Ukrainian].

8. Matveeva, I. V. (2007) Korrektirovka kachestva muki na osnove fermentnykh preparatov [Correction of quality of flour based on enzyme preparations]. Khleboprodukty - Bread products, 3, 55-57 [in Russian]. 
9. Drobot, V. (2011). Pohovorymo shche raz pro kharchovi dobavky ta ikh funktsionalnu rol v tekhnolohichnomu protsesi [Let's talk again about nutritional supplements and their functional role in the technological process]. Khlibopekarska $i$ kondyterska promyslovist Ukrainy - Bakery and confectionery industry of Ukraine, 5, 8-10 [in Ukrainian].

10. Meleshkina, E. A. (2005). Primenenie pishchevykh dobavok na melnitcakh [Application of food additives in mills]. Khleboprodukty - Bread products, 11, 40-42 [in Russian].

11. Kondratev, I. A. (2002). Primenenie fermentnykh preparatov na mukomolnykh zavodakh [The use of enzyme preparations in flour mills]. Zernovoe khoziaistvo - Grain economy, 5, 25-26 [in Russian].

12. Hamer, R. J., Tucker, G. A. (1991). Enzymes in the baking industry. Enzymes in Food Processing. L. F. J. Woods (Eds.). Glasgow: Blackie [in English].

UDC 664.71-11:664.64.016

\author{
Vasylyna Kovalova
}

\title{
DEVELOPMENT OF THE COMPLEX CORRECTOR FOR THE STABILIZATION OF THE QUALITY OF FLOUR AT THE MILLING PLANTS
}

Urgency of the research. The development of the flour mixture for improving the baking properties of the flour with the application of enzyme preparations - promising innovative direction of the milling industry.

Target setting. The use of enzyme preparations in the Ukrainian flour mills will make it possible to use the potential of raw materials as much as possible to stabilize the quality of the flour and meet the needs of bakery and confectionery industry.

Actual scientific researches and issues analysis. In the baking industry to improve the quality of bread used food additives and enhancers for various operating principle. Developed recipes for their introduction into the technological line of flour production.

Univestigated parts of general matters defining. There is no information in the literature on the use of direct-acting enzyme preparations directly at the Ukrainian flour mills as improver for stabilizing the quality of finished products.

The research objective. Improving the baking quality of wheat flour by introducing enzyme preparations.

The statement of basic material. The article presents studies on the quality adjustment of high quality Ukrainian flour with low baking properties, namely: low amylolytic activity (FN - $460 \mathrm{~s}$ ) and elastic properties of gluten, IDG index 51 units. As correctors, enzyme preparations of the German manufacturer Mühlenhimi with amylase and hemicelulase activity (Alphamalt A 6003) and sulfur-containing amino acid cysteine (Porit-L) were used. According to the results of the laboratory baking test, the influence of each corrector is determined separately and in a complex.

Conclusions. It is established that the complex of enzymes Alphamalt A 6003 and Porit-L leads to improvement of organoleptic and physical parameters of bread: increase in specific volume in 2.1 times, porosity from $71 \%$ to $84 \%$. For the first time, the article presents the recipes of a complex of enzymes for the correction of the quality of Ukrainian flour with low enzymatic activity. The research results can be used in the milling production to stabilize the quality of the finished product.

Keywords: wheat flour; enzyme preparations; gluten; Alphamalt A 6003; Porit-L; $\alpha$-amylase; hemicellulases.

Fig.: 4. References: 12.

УДК 664.71-11:664.64.016

\section{Василиса Ковалева}

\section{РАЗРАБОТКА КОМПЛЕКСНОГО КОРРЕКТОРА ДЛЯ СТАБИЛИЗАЦИИ КАЧЕСТВА МУКИ НА МУКОМОЛЬНЫХ ЗАВОДАХ}

\footnotetext{
Актуальность темы исследования. Разработка мучной смеси для улучшения хлебопекарньх свойств муки с использованием ферментных препаратов - перспективное инновационное направление развития мукомольной промьиилености.

Постановка проблемь. Использование ферментных препаратов на мукомольных заводах Украины даст возможность максимально использовать потенциал сырья, стабилизировать качество муки и удовлетворить потребности хлебопекарной и кондитерской промыиленности.

Анализ последних источников и публикаций. С челью улучшения качества хлеба в хлебопекарной промьиленности используют пищевые добавки и улучшители различного принципа действия. Разработаны рецептуры их внесения в технологическую линию производства мучных изделий.

Выделение неисследованных частей обцей проблемы. В литературе отсутствует информация о использовании в качестве улучшителей ферментных препаратов направленного действия непосредственно на мукомольных заводах Украины для стабилизации качества готовой продукции.

Целью работы является улучшение хлебопекарного качества пшеничной муки путем внесения ферментных препаратов.

Изложсение основного материала. В статье приведены исследования по корректировке качества украинской муки выстиего сорта с низкими хлебопекарными свойствами, а именно: низкой амилолитической активностью (ЧП 460 с) и упругими свойствами клейковины, показатель ИДК - 51 ус. ед. В качестве корректоров были использовань ферментные препарать немечкого производителя Мюленхими с амилазной и гемицелюлазной активностью (Аlрһатаlt A 6003) и серосодержамчая аминокислота ичитеин (Porit-L). По результатам пробной лабораторной выпечки установлено влияние каждого корректора как отдельно, так и в комплексе.
} 
TECHNICAL SCIENCES AND TECHNOLOGIES

Выводы в соответствии со статьей. Установлено, что комплекс ферментов Alphamalt A 6003 и Porit-L nриводит к улучшению органолептических и физических показателей хлеба: увеличение удельного объема в 2,1 раза, пористости с 71 до $84 \%$. В статье впервые приведены рецептуры комплекса ферментов для корректировки качества украинской муки с низкой ферментативной активностью. Результаты исследований могут быть использованы в мукомольном производстве для стабилизачии качества конечной продукции.

Ключевые слова: пшеничная мука; ферментные препараты; клейковина; Alphamalt A 6003; Porit-L; $\alpha$-амилаза; гемицелюллазы.

Рис.: 4. Библ.: 12.

Ковальова Василина Петрівна - аспірант, завідувач лабораторії «Оцінки хлібопекарської якості зерна та борошна», асистент кафедри технології переробки зерна, Одеська національна академія харчових технологій (вул. Канатна, 112, м. Одеса, 65039, Україна).

Ковалева Василиса Петровна - аспирант, заведующая лабораторией «Оценки хлебопекарного качества зерна и муки», ассистент кафедры технологии переработки зерна, Одесская национальная академия пищевых технологий (ул. Канатная, 112, г. Одесса, 65039, Украина).

Kovalova Vasylyna - PhD student, Head of the Laboratory «Bread quality grades of grain and flour», Assistant Professor of Technology of Grain Processing, Odessa National Academy of Food Technologies (112 Kanatna Str., 65039 Odessa, Ukraine).

E-mail: k.vasilisa@ukr.net

ORCID: http://orcid.org/0000-0003-2270-1337

ResearcherID: D-7510-2016

Ковальова В. Розробка комплексного коректора для стабілізації якості борошна на борошномельних заводах / В. Ковальова // Технічні науки та технології. - 2018. - № 1 (11). - С. 206-213. 